Science, Industry and Social Policy

By Kenneth Denbigh. Pp. vii + 103. (Edinburgh: Oliver and Boyd, Ltd., 1963.) 16s.

$\mathrm{T}$

HIS brief social criticism of applied science and industry is a notable tract for the times in the true lineage of Patrick Geddes and Lewis Mumford. Written with a refreshing freedom from jargon and giving ample and well-chosen references for further reading, it is a most stimulating challenge to thought as to what new forms of social progress we can achieve in our modern industrial societies. In particular, it challenges the over-emphasis on the economic factor, contending that the overdue orientation of the industrial order needs to be achieved in a social much more than in a purely economic sense. Moreover, while Prof. Denbigh pleads cogently for the individual and the need to preserve freedom of choice and opportunity in his conception of planning he displays the imagination and vision which mark Geddes and Mumford at their best.

The seven chapters of this book in which, successively, Prof. Denbigh discusses trenchantly the short-comings and primitiveness of industrialism as it moves forward, as he believes, into a new phase, the rise of 'economicism', as he describes the practice of accepting economic factors as if they were the only criterion, the relations of consumers versus producers, in which he pleads that work should be so planned and organized as to provide satisfaction to the producer; the paradox of resources, in which our failures in planning industry, towns, transport, ete., are overwhelmingly pilloried, on transcending the machine, on the public conscience and private uncertainty, and on science and world conditions abroad in stimulating suggestions. Questions are raised, implicitly or explicitly, and in a context of realism and vision, which should set the reader searching for an answer. Here is no blue-print for a new social or industrial order but some very shrewd pointers to the way in which that order may be created. The scientist will find some questions about the control of research expenditure or the relations between the scientist and Government which are the more suggestive because they are so unexpectedly raised. The book is short but never superficial, well written and full of ideas, many of which have long since been ventilated but are now formulated with fresh meaning in the context of to-day's needs and potentialities.

R. BRIghtMaN

\section{Enzymes and Drug Action}

Edited by Dr. J. L. Mongar and A. V. S. de Reuck. (Ciba Foundation Symposium, jointly with the Coordinating Committeo for Symposia on Drug A.ction.) Pp. xv+556. (London: J. and A. Churchill, Ltd., 1962.) 65s. net.

THE scope of this symposium is not as wide as its title would suggest. On the enzymatic side, it includes a paper on carbonic anhydrase and some discussion of microsomal enzymes involved in drug metabolism, but it is weighted disproportionately towards acetyl choline esterase. The drugs considered are mainly those affecting muscular contraction or acting on the central nervous system; the action of some hormones is also discussed.

The symposium, which was held in March 1961, was in two parts. The first part was a large gathering at which nineteen formal papers were presented. A report of this meeting occupies the first 400 pages of the book. The papers are preponderantly pharmacological in outlook, variable in standard, and many are repetitions of work published elsewhere. The discussions in this part are scrappy and irritating to read; they contribute little of scientific value, though in places they show a lively atmosphere of controversy. The second part, reported in tho last 120 pages of the book, is much more valuable. It records the informal discussions of a selocted group of about thirty well-known physiologists, pharma- cologists, biochemists and physical chemists on such debatable and elusive problems as active transport, the nature of receptor sites and the mechanism of insulin action. The meetings wore in four sessions devoted to the general topics of enzymes, receptors, and interactions at sub-cellular and cellular levels. These discussions reveal starkly the lack of common ground between the participants in their basic assumptions and in their methods. A lack of agreement in the interpretation of their results is scarcely surprising, and the outcome of most of the arguments is inconclusive, but the conflict is fascinating and illuminating to the reader. This is a big, untidy book plentifully sprinkled with misprints. It is not a book to keep for reference, but parts of it should provide stimulating thoughts for anyone interested in the way in which drugs work.

G. A. SNow

\section{Annual Review of Nuclear Science}

Vol. 12. Edited by Emilio Segre. Pp. 633. (Palo Alto, California: Annual Reviews, Inc., 1962.) 8.50 dollars.

$\mathrm{O}$ CE again the editors of the Annual Review of Nuclear Science present a series of review articles by authorities in a wide range of specialist topics in nuclear physics. The technical articles cover the subjects of the preparation of thin films for sources and targets, semiconductor particle detectors and research reactors, and theoretical articles cover the subjects of compound statistical features in nuclear reactions, electron exchange reactions, disper. sion relation methods in strong interactions, and nuc lear astrophysics. In between these extremes are articles on inelastic electron scattering, polarization measurements on $\beta$ - and $\gamma$-rays, and an article on the Mössbauer effect. With a more chemical bias are two articles on isotopic exchange reactions and free radicals in irradiated biological materials.

It would be a wide-ranging physicist indeed who found more than half these articles of more than passing interest, but all active physicists will find this volume a valuable work of reference.

T. E. Cranshaw

\section{A New Mesozoic Flora from Tico, Santa Cruz Province, Argentina}

By S. Archangelsky. Bulletin of the British Museum (Natural History): Geology, 8, No. 2. Pp. 47, 12 plates. (London: British Museum (Natural History), 1963). $30 s$.

CELDOM now does a fossil flora prove almost entirely $S$ new, but this one from the Upper Mesozoic of the Argentine does. The present paper deals with Pteridosperm-like leaves and conifer shoots (with a few associated fructifications). They have well-preserved cuticles which are described in detail. The stomata in some are remarkably like those of Cycas revoluta, though the finely divided leaf looks like a fern. They are placed in five new genera, and, while the number of genera of such leaves is alroady inconveniently large, it is hard to see what else could have been done with leaves as odd as these. A little two-seeded fruit is associated with one of them; it is quite unlike anything produced by a cycad, but more like Caytonia.

Most of the conifers are new species of Brachyphyllum; one is of interest in being associated with Araucaria-like male cones. One of the most interesting species in the flora and the only one previously known is Athrotaxis ungeri, previously described by Halle on material with no cuticles but with female cones. The cuticle of this fossil now proves very close to that of $A$. cupressoides, which still survives in Tasmania; it is thus a gymnosperm of greatly reduced range.

We may hope that further collection and study will add considerably to knowledge of these plants, which may represent some entirely unfamiliar families.

TOM M. Harris 